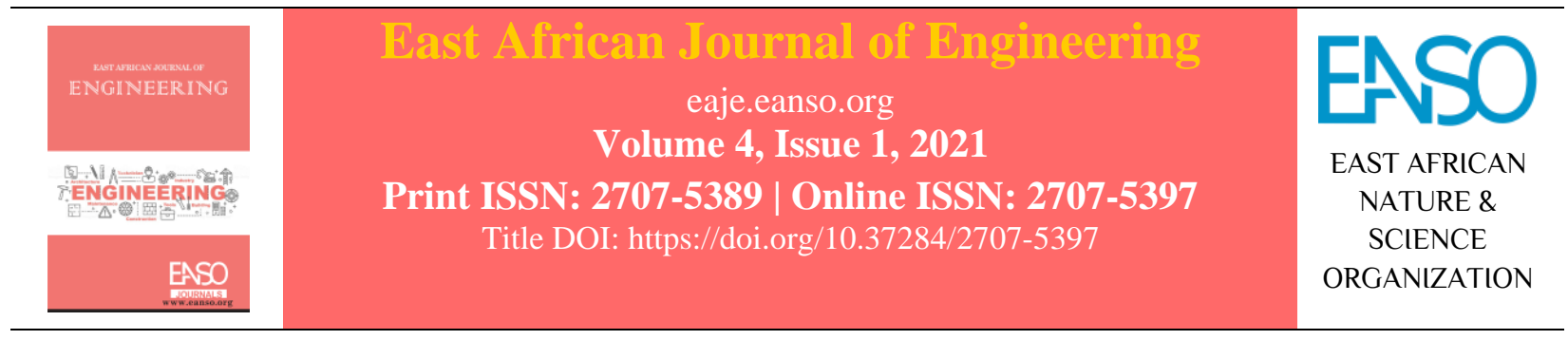

Original Article

\title{
Effect of Firing Temperature on some Mechanical Properties of Osun State Ceramic Tiles.
}

\author{
Oluranti Abiola $^{1 *}$, Adekola Oke ${ }^{2}$, Babatunde Omidiji ${ }^{2}$ \& Dare Adetan ${ }^{2}$ \\ ${ }^{1}$ Elizade University, 340271, Ilara-Mokin, Ondo State, Nigeria. \\ ${ }^{2}$ Obafemi Awolowo University, Ile-Ife, 22005, Osun State, Nigeria. \\ * Author for Correspondence ORCID ID: https://orcid.org/0000-0002-8197-9526; Email: visitoluranti@gmail.com.
}

Article DOI: https://doi.org/10.37284/eaje.4.1.467

\section{Publication Date: ABSTRACT}

09 November 2021 The work evaluates the effect of firing temperature on the mechanical properties of ceramic tiles. This was with the view to determine the optimum

Keywords: processing condition for Osun State ceramic tiles. Ceramic raw materials collected from Osun State were batched using clay-feldspar-silica sand

Clay, blending ratio of 5:4:1, 5:3:2, 5:2:3, 5:1:4, 6:3:1, 6:2:2, 6:1:3, 7:2:1, 7:1:2 and

Feldspar, 8:1:1 by weight; and homogeneously mixed. Three replica samples were

Silica Sand, moulded by the method of dry forming, fired at 1200,1300 and $1400{ }^{\circ} \mathrm{C}$ and subjected to breaking and flexural strength tests using the Universal Testing

Triaxial Blend, Machine while the hardness test was carried out on a Moh's scale. The results Mechanical Properties, showed that breaking strength, flexural strength and Moh's hardness fell

Ceramic Tiles. within the range 199.43 to $325 \mathrm{~N}, 11.97$ to $19.50 \mathrm{~N} / \mathrm{mm}^{2}$ and 2.5 to $4 \mathrm{MH}$ respectively, while Figures revealed that samples with $60 \%$ clay, $10 \%$ feldspar and $30 \%$ silica sand fired at $1320{ }^{\circ} \mathrm{C}$ will process the best mechanical properties. In conclusion, ceramic raw materials collected from Osun State are viable for ceramic tile production.

\section{APA CITATION}

Abiola, O., Oke, A., Omidiji, B., \& Adetan, D. (2021). Effect of Firing Temperature on some Mechanical Properties of Osun State Ceramic Tiles East African Journal of Engineering, 4(1), 13-21. https://doi.org/10.37284/eaje.4.1.467

\section{CHICAGO CITATION}

Abiola, Oluranti, Adekola Oke, Babatunde Omidiji, \& Dare Adetan. 2021. "Effect of Firing Temperature on some Mechanical Properties of Osun State Ceramic Tiles". East African Journal of Engineering 4 (1), $13-21$. https://doi.org/10.37284/eaje.4.1.467.

\section{HARVARD CITATION}

Abiola, O., Oke, A., Omidiji, B \& Adetan, D. (2021) "Effect of Firing Temperature on some Mechanical Properties of Osun State Ceramic Tiles”, East African Journal of Engineering, 4(1), pp. 13-21. doi: 10.37284/eaje.4.1.467.

\section{IEEE CITATION}

O., Abiola., A. Oke., B. Omidiji \& Adetan, D. "Effect of Firing Temperature on some Mechanical Properties of Osun State Ceramic Tiles," EAJE, vol. 4, no. 1, pp. 13-21, Nov. 2021.

13 This work is licensed under a Creative Commons Attribution 4.0 International License. 


\section{MLA CITATION}

Abiola, Oluranti, Adekola Oke, Babatunde Omidiji, \& Dare Adetan. "Effect of Firing Temperature on some Mechanical Properties of Osun State Ceramic Tiles." East African Journal of Engineering, Vol. 4, no. 1, Nov. 2021, pp. 13-21, doi:10.37284/eaje.4.1.467.

\section{INTRODUCTION}

Ceramic tiles are highly vitrified materials produced from a triaxial blend of kaolin $\left(\mathrm{Al}_{2} \mathrm{Si}_{2} \mathrm{O}_{5}(\mathrm{OH})_{4}\right)$, quartz $\left(\mathrm{SiO}_{2}\right)$ and feldspar $(\mathrm{K}, \mathrm{Na}, \mathrm{Ca})_{2} \mathrm{O} . \mathrm{Al}_{2} \mathrm{O}_{3}$. $6 \mathrm{H}_{2} \mathrm{O}$ ) (Irabor et al., 2014; Toe et al., 2016; El Nouhy, 2013; Martín-Márquez et al., 2008; Misra et al., 2013; Soni et al., 2015). It is primarily a hygiene product made of the porous body with a coating of white or coloured glaze extensively used in the living room, bathrooms, kitchens, medical centres, laboratories, schools, public conveniences, and shopping malls (El Nouhy, 2013). Ceramics can also be inorganic, non-metallic crystalline materials comprising metal, nonmetal or metalloid atoms primarily held by ionic and covalent bonds (European Commission, 2007; Adindu et al., 2014; Solanki \& Shah, 2016). Ceramic products are brittle, hard, strong in compression, weak in shearing and tension.

Amount, size and distribution of porosity are among the important factors which affect the physical and mechanical properties of ceramic tiles (Ozturk \& Ay, 2014). Mechanical properties common to ceramic tiles are breaking strength and flexural strength, Impact resistance, Resistance to deep abrasion, Hardness, Coefficient of friction and Tensile strength.

The flexural strength also known as modulus of rupture or bending strength or transverse rupture is the stress in a material just before it yields in a flexure test (Ashby, 2005) or an indication of product breaking strength (Alege \& Alege, 2013). Flexural strength of ceramics is an important property for all the applications involving impact loading conditions (El Nouhy, 2013; Iseri et al., 2010; Belenky \& Rittel, 2012; Mojiska et al., 2016), with tiles falling into that category due to various machining operations carried out on it before and after installation. The limits of breaking strength and flexural strength of any specimen are determined by both water absorption and thickness of the specimen and it depends on the body composition, dimensions, and morphology of the flaws (El Nouhy, 2013). The flexural strength represents the highest stress experienced within the material at the point of failure. Ceramic systems usually exhibit a low modulus of rupture (Ashby, 2005). Hardness, meanwhile, is the resistance of a material to plastic deformation, usually by scratch, indentation rebound (Chinn, 2009).

The mechanical properties of any ceramic body are dependent on the properties of the raw material and firing temperature. According to El Nouhy (2013) and Soni et al. (2015), the mechanical properties of ceramics depend on the amount of mullite formation which is a factor of the type, properties and proportion of the clay used as well as the firing temperature. Meanwhile, several researchers have reported different triaxial blends as well as diverse optimum firing temperatures for ceramic tiles production. Braganca and Bargmann (2004) reported $1340{ }^{\circ} \mathrm{C}$; in the works of Amoros et al (2007) and Idowu, (2014), between 1190 and 1220 ${ }^{\circ} \mathrm{C}$ was reported; for El-fadaly (2015) it was between 1190 and $1230{ }^{\circ} \mathrm{C}$; The American Ceramic Society (2005) stated $1400{ }^{\circ} \mathrm{C}$ as the maximum firing temperature; while Mathew \& Fatile (2014) reported $1218{ }^{\circ} \mathrm{C}$ as suitable firing temperature. Consequently, the work seeks to determine the effect of firing temperature on the mechanical properties of ceramic tiles.

\section{MATERIALS AND METHOD}

\section{Materials and Sources}

The clay mineral used in this study was kaolinite clay (Oke \& Omidiji, 2016), collected from Ipetumodu, headquarters of the Ife North Local

14 | This work is licensed under a Creative Commons Attribution 4.0 International License. 
Government area of Osun State, Nigeria. Silica sand was collected from the Isasa River; the river serves as the boundary between the Ayedaade and Ife North Local Government areas of Osun State, Nigeria. Feldspar was collected from Osogbo, the capital of Osun State, Nigeria. The three raw materials collected were beneficiated separately as specified by Abiola et al., (2019).

\section{Preparation of Materials}

The ceramic raw materials (clay, feldspar and silica sand) were homogeneously mixed, prepared into ten different blends of 5:4:1, 5:3:2, 5:2:3, 5:1:4, 6:3:1, $6: 2: 2,6: 1: 3,7: 2: 1,7: 1: 2$ and 8:1:1 ratio by weight; and designated as blend A, B, C, up to J respectively and fired as described by Abiola et al., (2021). Three replicate ceramic samples for flexural strength (140 x $45 \times 5 \mathrm{~mm})$, breaking strength (140 x $45 \times 5 \mathrm{~mm})$ and hardness test $(20 \times 20 \times 10 \mathrm{~mm})$ were made from each blend, A - $\mathbf{J}$ of the ceramic materials by compacting them at $40 \mathrm{MPa}$ pressure as specified by Bresciani et al. (2004) to recommended size for the different test.

After forming, the samples were dried by convection in an open laboratory drying oven (model DHG-9101-2A manufactured by Searchtech Instrument) where heated air was circulated around the ceramic samples. The air around the samples was kept at $95^{\circ} \mathrm{C}$ to remove the water content since water is expected to evaporate from the ceramic mixture below $100{ }^{\circ} \mathrm{C}$. The materials were kept under this condition for a period of 20 hours following the method of Br.MSME-DI (2011). This drying process is expected to prevent differential shrinkage, warping, cracking and distortion of the eventual product.

Prior to firing, the ceramic samples were heattreated in the laboratory drying oven at a temperature of $300{ }^{\circ} \mathrm{C}$ in line with the recommendation of Br.MSME-DI (2011) to provide additional drying, vaporize or decompose organic additives and other impurities, as well as to remove residual, crystalline, and chemically bound water. As proposed by Br.MSME-DI (2011), the ceramic samples were kept in the kiln for 20 hours while the temperature of $300{ }^{\circ} \mathrm{C}$ was held constant. After this period, the ceramic samples were brought out of the kiln and allowed to cool normally at ambient temperature and then fired in a furnace (model XD$1700 \mathrm{M}$ manufacturer by Zhengzhou Brother Furnace Company, China). The experimental firing temperatures of 1200,1300 and $1400{ }^{\circ} \mathrm{C}$ were used. These temperatures were employed since according to Abiola \& Oke (2017) Ipetumodu clay begin to disintegrate at $1450{ }^{\circ} \mathrm{C}$. Also, $1400{ }^{\circ} \mathrm{C}$ was used as the maximum firing temperature, since according to the American Ceramic Society (2005), it is the maximum sintering temperature for ceramic tile production. The lower temperatures $\left(1200{ }^{\circ} \mathrm{C}\right.$ and $1300{ }^{\circ} \mathrm{C}$ ) were required to evaluate the behaviour of the local tiles produced below the recommended maximum firing temperature for ceramic products. This was because diverse sintering temperatures between 1190 and $1340{ }^{\circ} \mathrm{C}$ have been recommended by various researchers (Braganca \& Bergmann, 2004; Amoros et al., 2007; Idowu, 2014; El-Fadaly., 2015). The samples were held at the respective firing temperatures for about 1 hour soaking time to ensure equalization of temperature throughout the cross-section of the samples (Ashby, 2005; Abeid \& Park, 2018). Thereafter, the samples were kept in the kiln for a cycle of at least 18 hours where it was cooled, in line with Br.MSME-DI (2011).

\section{Mechanical Property Test}

After cooling, the ceramic tiles were off-loaded from the kiln and subjected to flexural strength and breaking strength test according to ISO 10545-3 (1996) while the hardness test was investigated using Moh's scale hardness test method in line with El Nouhy (2013).

The breaking strength was calculated from equation (1) as:

$S=\frac{F L}{b}$

15 | This work is licensed under a Creative Commons Attribution 4.0 International License. 
where, $S$ is the breaking strength, in Newton; $F$ is the breaking load, in Newton; $L$ is the distance between the supporting rods, in millimetres (65 $\mathrm{mm}) ; b$ is the width of the test specimen, in millimetres as shown in Figure 1.

From the same test (Fig. 1), modulus of rupture also known as flexural strength was calculated for each sample of ceramic tiles using equation (2) (1996).
$R=\frac{3 S}{2 h^{2}}$

where $R$ is the modulus of rupture, in $\mathrm{N} / \mathrm{mm}^{2} ; S$ is the breaking strength or force, in Newton; $h$ is the minimum thickness of the test tile specimen, in millimetres.

Figure 1: Placement of specimen on Universal Strength Testing Machine for breaking strength and flexural strength test

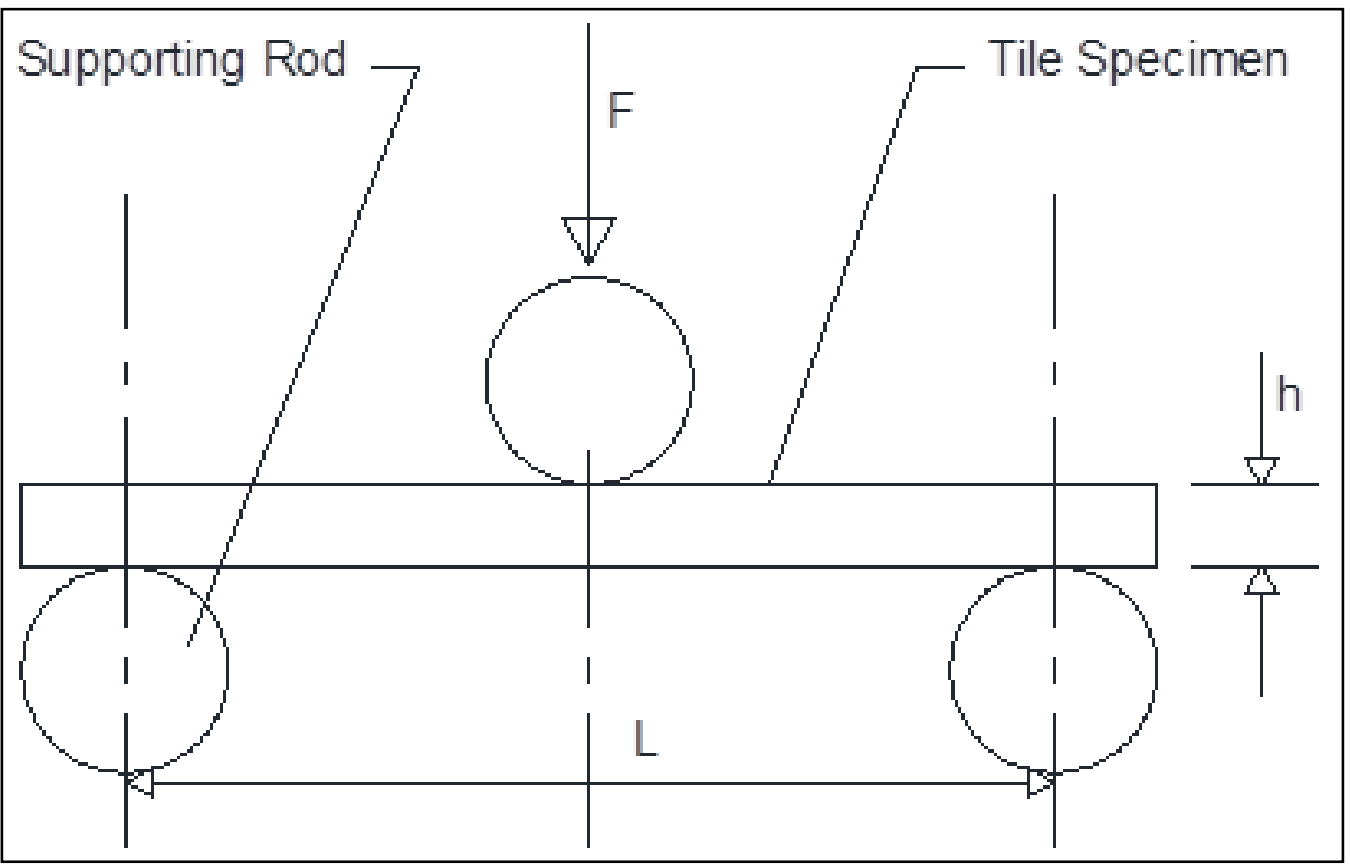

The hardness test was investigated using Moh's scale hardness test method in line with El-Nouhy (2013). A minimum of three replicate tests were carried out on each specimen (20 x $20 \times 10 \mathrm{~mm})$. The constituents of the specimen with the highest Moh's hardness that resulted in no more than one scratch were recorded.

\section{Experimental Design}

Design Expert 6.0.8 Portable was used to design the experiment using the surface response method. Two-factor design matrix linear models were applied in designing the experiment to determine the effect of firing temperatures $\left(1200{ }^{\circ} \mathrm{C}, 1300{ }^{\circ} \mathrm{C}\right.$ and $\left.1400{ }^{\circ} \mathrm{C}\right)$ and triaxial blend ratios (5:4:1, 5:3:2, $5: 2: 3,5: 1: 4,6: 3: 1,6: 2: 2,6: 1: 3,7: 2: 1,7: 1: 2$ and $8: 1: 1)$ on some mechanical properties (flexural strength, breaking strength and hardness) of ceramic tiles. Design matrix of sixty (60) experiments designed for two factors were used on each combination of firing temperature and blending ratio for mechanical properties.

\section{RESULTS AND DISCUSSION}

\section{Breaking and Flexural Strength}

The flexural strength of the samples which is a function of the breaking strength generally increases

16| This work is licensed under a Creative Commons Attribution 4.0 International License. 
as the temperature increased from $1200{ }^{\circ} \mathrm{C}$ to just above $1300{ }^{\circ} \mathrm{C}$ and then fell as the temperature further increased from just above $1300{ }^{\circ} \mathrm{C}$ to 1400 ${ }^{\circ} \mathrm{C}$ as shown in Figures 2 and 3.

The rising strength with increased firing temperature may be due to liquid or glass phase formation as a result of a high percentage of alkaline oxides $\left(\mathrm{Na}_{2} \mathrm{O}\right.$ and $\left.\mathrm{K}_{2} \mathrm{O}\right)$ present in the feldspar (Nouhy, 2013; Kimambo et al., 2014). As a result, a large amount of liquid phase form, fill and reduce pore spaces in the ceramic body. This results in increasing the flexural strength of the samples with increasing firing temperature (Hettiarachchi et al., 2014). The fall in the breaking strength and flexural strength as firing temperature increased from 1300 ${ }^{\circ} \mathrm{C}$ to $1400{ }^{\circ} \mathrm{C}$ may be due to bloating (Hettiarachchi et al., 2014) which results in increased porosity within the same temperature range. (Kimambo et al., 2014; Hettiarachchi et al., 2014).

The result also shows that the strength of the samples increases as silica sand content increases and feldspar reduces. This may be due to a high percentage of alkaline earth oxides $(\mathrm{CaO}$ and $\mathrm{MgO})$ contained in the silica sand even after beneficiation. Alkaline earth oxides can form high viscous liquid phases at a high temperature which enabled the formation of new crystals that enhance the densification and strength of the ceramic body (Hettiarachchi et al., 2014). Silica sand contributes higher strength to the ceramic body than what the glass phase reached in $\mathrm{Na}_{2} \mathrm{O}$ and $\mathrm{K}_{2} \mathrm{O}$ which are abundant in feldspar.

Figure 2: Breaking Strength of the ceramic tile samples fired at different temperatures

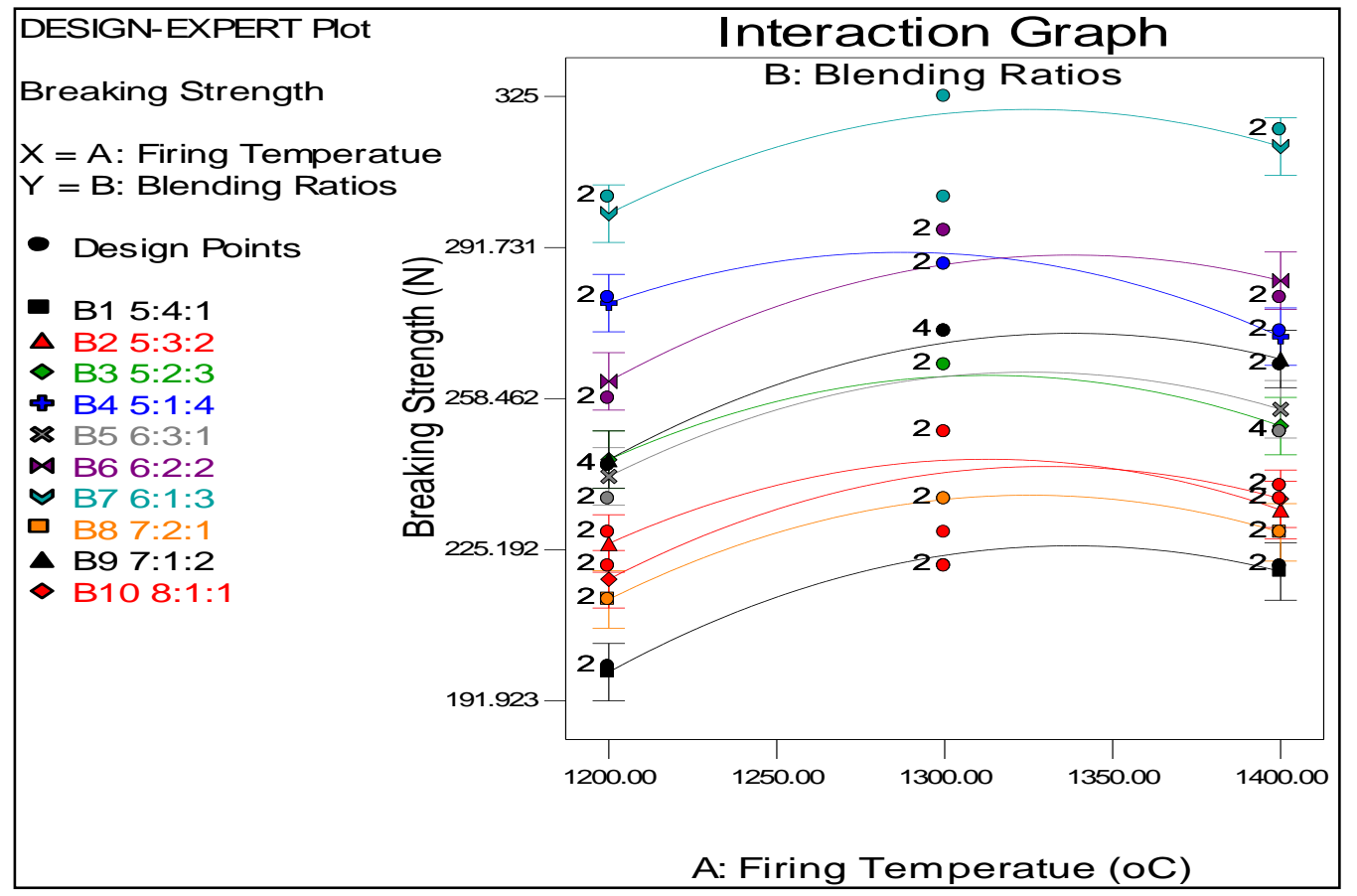

17 | This work is licensed under a Creative Commons Attribution 4.0 International License. 
Figure 3: Flexural strength of the ceramic tile samples fired at different temperatures

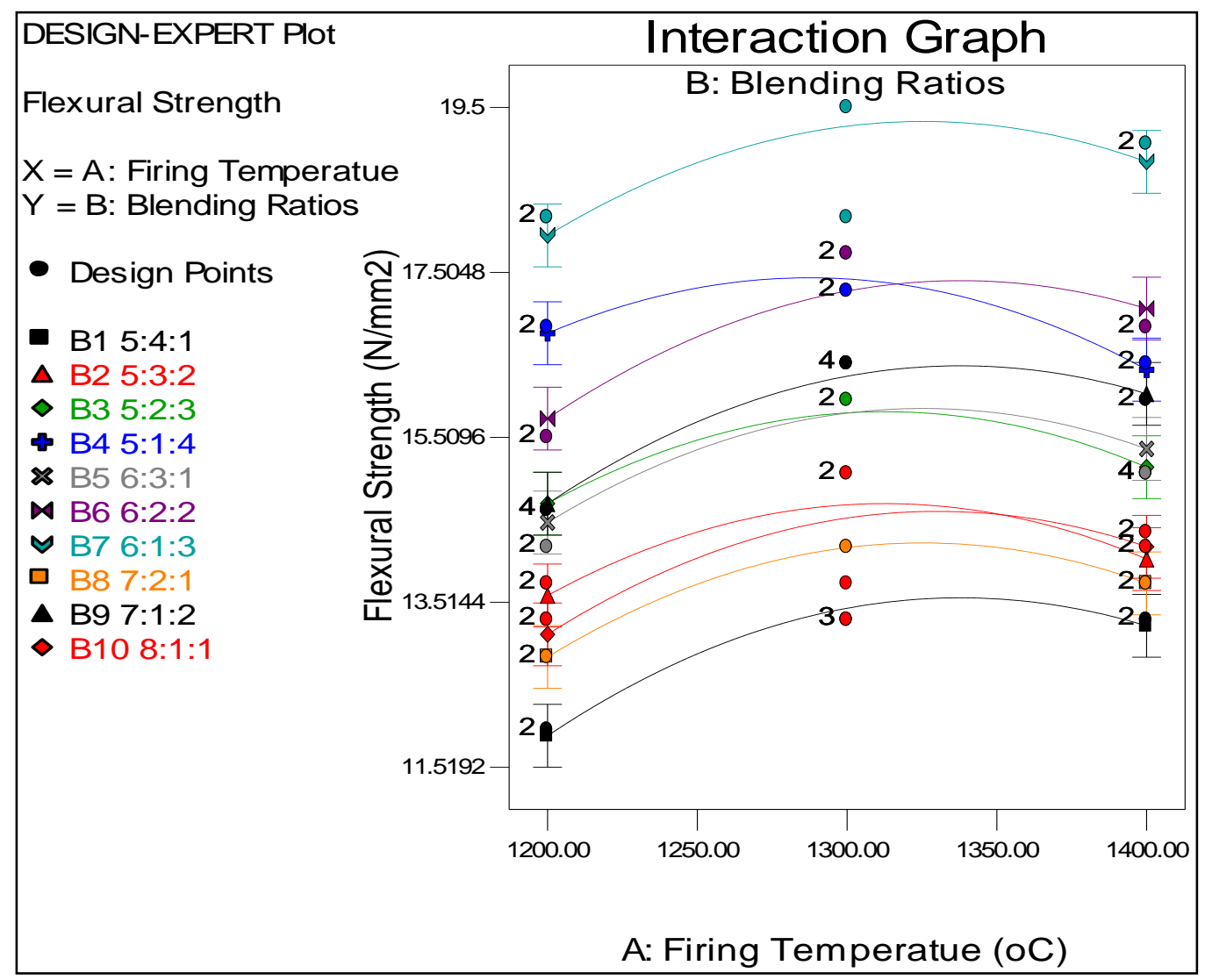

The main function of silica sand is to reduce the ceramic body's tendency to warp or distort when fired to high temperatures which result in the formation of relatively large amounts of molten glass in the body (El Nouhy, 2013). Hence, samples containing high silica sand generally show higher strength than those containing more feldspar.

The results further show that the minimum breaking strength $(199.43 \mathrm{~N})$ and flexural strength (11.97 $\mathrm{N} / \mathrm{mm}^{2}$ ) were recorded for sample "A" fired at 1200 ${ }^{\circ} \mathrm{C}$ while the maximum breaking strength $(325 \mathrm{~N})$ and flexural strength $\left(19.50 \mathrm{~N} / \mathrm{mm}^{2}\right)$ were recorded for sample $\mathrm{G}$ fired at $1300{ }^{\circ} \mathrm{C}$ fall way short of the ISO recommended standard of $600 \mathrm{~N}$ and $35 \mathrm{~N} / \mathrm{mm}^{2}$ respectively for tiles that are less than $7.5 \mathrm{~mm}$ thick. Meanwhile, Chukwudi et al. (2012) described 20 $\mathrm{MPa}$ to $35 \mathrm{MPa}$ as the flexural strength for normal floor tiles irrespective of its thickness though it recorded a much higher flexural strength of between
$25 \mathrm{MPa}$ to $59 \mathrm{MPa}$ in its study after adding different percentages of steel slag to the mixture of clay, feldspar, and silica sand material. Ogundare et al. (2015) recorded a similarly high flexural strength ranging from $21 \mathrm{MPa}$ to $54 \mathrm{MPa}$. El-Nouhy (2013) alighted between $13.6 \mathrm{~N} / \mathrm{mm}^{2}$ and $24.79 \mathrm{~N} / \mathrm{mm}^{2}$ as the flexural strength for the 14 different ceramic tile samples produced and collected from Egypt.

\section{Moh's Hardness}

The result showed that the hardness of the ceramic samples increases as the firing temperature rises and then began to drop with a further increase in temperature as shown in Figure 4. The increased Moh's hardness with an increase in the firing temperature from $1200{ }^{\circ} \mathrm{C}$ to $1300{ }^{\circ} \mathrm{C}$ may be as a result of the samples' pores being filled with the liquid phase of the molten feldspar (Nouhy, 2013; Kimambo et al., 2014). However, the eventual

18 | This work is licensed under a Creative Commons Attribution 4.0 International License. 
decrease in the hardness as temperature rises from $1300{ }^{\circ} \mathrm{C}$ to $1400{ }^{\circ} \mathrm{C}$ may be as a result of bloating which resulted from gas enclosed within the pores of the ceramic articles (Hettiarachchi et al., 2014).

Figure 4: Moh's hardness of the ceramic tile samples fired at different temperatures

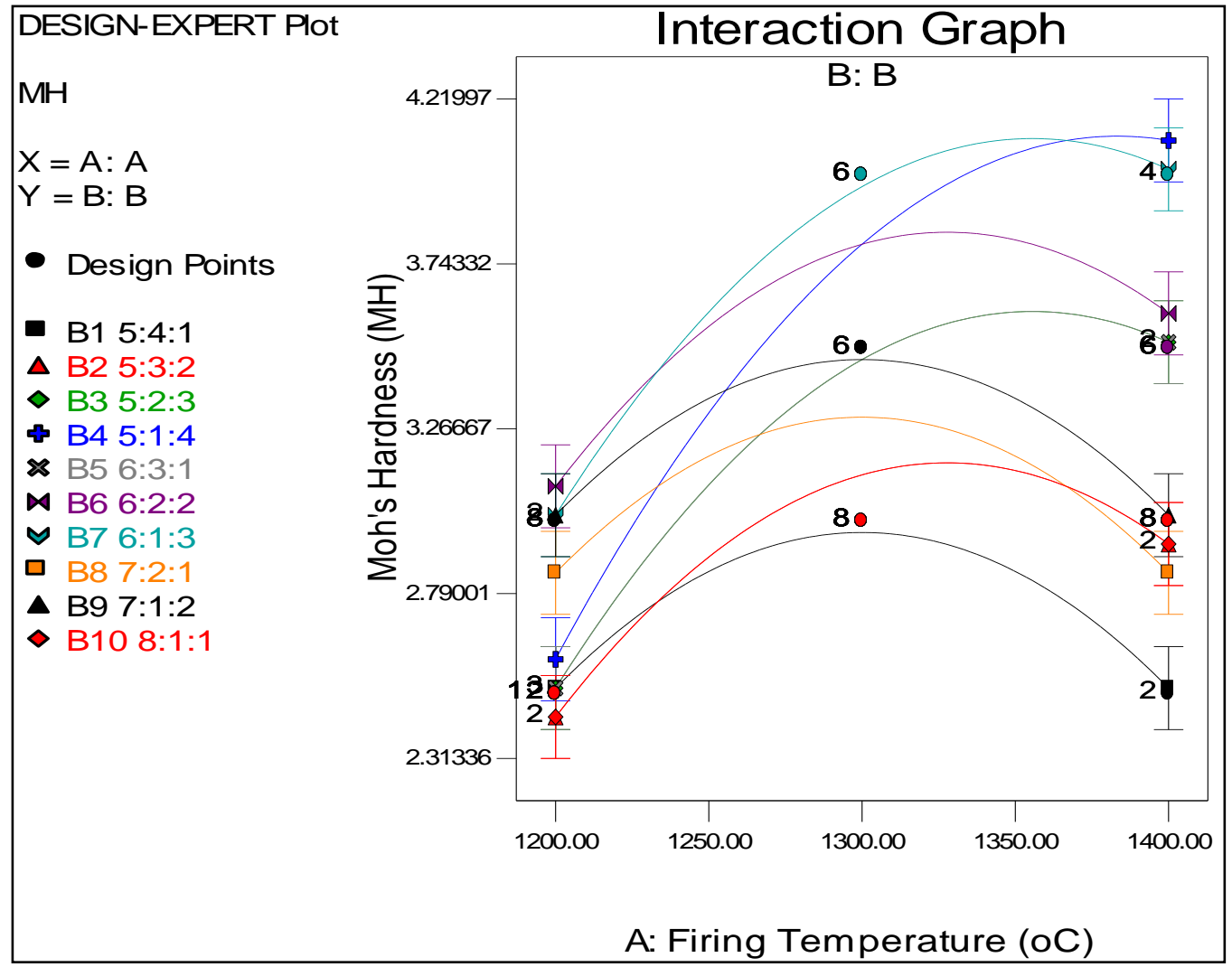

\section{CONCLUSION}

There is appreciation in the mechanical properties of ceramic tiles as firing temperature increases from $1200{ }^{\circ} \mathrm{C}$ to just above $1300{ }^{\circ} \mathrm{C}$ and these properties deteriorate with a further increase in temperature. Therefore, Figures 1 to 3 revealed that the ceramic sample will attain the best mechanical properties at about $1320{ }^{\circ} \mathrm{C}$. The ceramic sample produced from Osun State raw materials in this study is good for wall tiles since the strength is just about the minimum $(20 \mathrm{~N} / \mathrm{mm} 2)$ rather than the maximum (35 $\mathrm{N} / \mathrm{mm} 2$ ). Meanwhile, ceramic sample ' $\mathrm{G}$ ' with $60 \%$ clay, $10 \%$ feldspar and $30 \%$ silica sand produced the sample with the best breaking strength (325.00 $\mathrm{N})$, flexural strength (19.50 N/mm2), Moh's hardness (4 MH). Also, samples with $60 \%$ clay make the sample with the best strength.

\section{REFERENCES}

Abeid S., \& Park S. E., 2018. Suitability of vermiculite and rice husk ash as raw materials for production of ceramic tiles, International Journal of Materials Science and Applications, Vol. 7 (2), 39-48.

Abiola O. A. \& Oke A. O., 2017. Carbonised Palm Kernel Shell Effect on the Physico-Chemical Properties of Clay-Sand Mixture. Journal of Applied Science, Engineering and Technology, Vol. 17 (1), 17-23.

Abiola, O. A., Oke, A. O., Omidiji, B. V., \& Adetan, D. A. (2019). The effect of beneficiation on some properties of Osun State ceramic raw materials. Journal of Casting \& Materials Engineering, 3(3), 62-66.

19 | This work is licensed under a Creative Commons Attribution 4.0 International License. 
Abiola, O. A., Oke, A. O., Omidiji, B. V., \& Adetan, D. A. (2021). The effect of raw materials on some physical properties of Osun State ceramic tiles. Journal of Engineering Studies and Research, 27(1), 7-12.

Adindu, C. I., Moses, J., Thaddeus, C. A., \& Tse, D. T. (2014). Exploring ceramic raw materials in Nigeria and their contribution to nation's development. American Journal of Engineering Research, 3(9), 127-134.

Alege, E. K., \& Alege, T. S. (2013). Selected clays of the Bida and Anambra basins of Nigeria: Their characteristics, fired properties and ceramic-suitability. International Journal of Science and Technology, 2(7), 560 - 567.

Amoros, J. L., Orts, M. J., Garcia-Ten, J., Gozalbo, A., \& Sanchez, E. (2007). Effect of the green porous texture on porcelain tile properties. Journal of the European Ceramic Society, 27, 2295-2301.

Ashby, M. F. (2005). Materials selection in mechanical design (3rd ed.). Pergamon Press, Butterworth-Heinemann Linacre House, Jordan Hill, Oxford.

Belenky, A., \& Rittel, D. (2012). Static and dynamic flexural strength of $99.5 \%$ alumina: Relation to surface roughness. Mechanics of Materials, 54, 91-99.

Braganca, S. R., \& Bergmann, C. P. (2004). Traditional and glass powder porcelain: Technical and microstructure analysis. Journal of European Ceramic Society, 24(8), 23832388.

Bresciani, A., Ricci, C., \& Imola S. (2004). Innovative process for ceramic tile manufacturing by double pressing with continuous precompaction. Castlelon, 49-60.

Br.MSME-DI, (2011). Ceramic glazed wall tiles, small scale production enterprise. W.B.S.I.D.C
Industrial Estate, J.P. Avenue, Durgapur-12, 1 18.

Chinn, R. L. (2009). Hardness, bearings, and the Rockwells. Advanced Materials \& Processes, 167(10), 29-31.

Chukwudi, B. C., Ademusuru, P. O., \& Okorie, B. A. (2012). Characterization of sintered ceramic tiles produced from steel slag. Journal of Minerals and Materials Characterization and Engineering, 11, 863-868.

El-Fadaly, E. (2015). Characterization of porcelain stoneware tiles based on solid ceramic wastes. International Journal of Science and Research, 4(1), 602-608.

El Nouhy, H. A. (2013). Assessment of some locally produced Egyptian ceramic wall tiles. Housing and Building National Research Center Journal, 9, 201-209.

European Commission (2007). Reference document on best available techniques in the ceramic manufacturing industry. Retrieved September 9, 2018, from http://eippcb.jrc.es

Hettiarachchi, P., Wickramasinghearachchi, R. C., \& Pitawala, H. M. T. G. A. (2014). A comparison of fluxing effects of granite and feldspar on red clay body composition. Journal of Geological Society of Sri Lanka, 16, 101-108.

Idowu, I. O. (2014). Production of vitrified porcelain tiles using local raw materials from south western Nigeria. Journal of Emerging Trends in Engineering and Applied Sciences, 5(6), 421-428.

Irabor, P. S. A., Jimoh, S. O, \& Omowumi, O. J. (2014). Ceramic raw materials development in Nigeria. International Journal of Scientific and Technological Research, 3(9), 275-287.

Iseri, U., Ozkurt, Z., Kazazoglu, E., \& Kucukoglu, D. (2010). Influence of grinding procedures on

20 This work is licensed under a Creative Commons Attribution 4.0 International License. 
the flexural strength of zirconia ceramics. Brazilian Dental Journal, 21(6), 528-532.

ISO 10545, (1996). EN ISO norms for ceramic tiles - Testing methods. Retrieved September 25, 2018, from www.norfloor.no/media/ wysiwyg/DIY/ISO_10545-2.pdf.

Kimambo, V., Philip, J. Y. N., \& Lugwisha, E. H. (2014). Suitability of Tanzanian kaolin, quartz and feldspar as raw materials for the production of porcelain tiles. International Journal of Science, Technology and Society, 2(6): 201-209.

Martín-Márquez, J., Rincón, J., \& Romero, M. (2008). Effect of firing temperature on sintering of porcelain stoneware tiles. Ceramics International, 34, 1867-1873.

Mathew, G. O., \& Fatile, B. O. (2014). Characterization of vitrified porcelain tiles using feldspar from three selected deposits in Nigeria. Research Journal of Recent Sciences, 3(9), 6772.

Mijoska, A., Bajraktarova-Valjakova, E., Stevkoska-Korunovska, V., Gigovski, N., Kapusevska, B., \& Bajevska, J. (2016). Flexure strength of zirconia veneering ceramics. Journal of Dental and Medical Sciences, 15(1), 85-88.

Misra, S. N., Machhoya, B. B., \& Savsani, R. M. (2013). Thermophysical characteristics of vitrified tile polishing waste for use in traditional ceramics-an initiative of CGCRI, Naroda centre. International Conference on Ceramics, Bikaner, India. International Journal of Modern Physics: Conference Series, 22, 118-133.

Ogundare, T., Fatile, O., \& Ajayi, O. (2015). Development and characterization of Parian bodies using feldspar from two selected deposits. Leonardo Electronic Journal of Practices and Technologies, 27, 147-156.

Oke, A. O., \& Omidiji, B. V. (2016). Investigation of same moulding properties of a Nigeria clay- bonded sand. Archives of Foundry Engineering, 16(3), 71-76.

Ozturk, Z. B., \& Ay, N. (2014). Investigation of porosity of ceramic tiles by means of image analysis method. Journal of Ceramic Processing Research, 15(6), 393-397.

Solanki, K. M., \& Shah, S. R. (2016). Analysis of drying process in ceramic tiles industries. International Journal of Advance Research and Innovative Ideas in Education, 2(3), 409-418.

Soni, A., Mathur, R., \& Kumar, K. (2015). Study on particle size distribution and its effects on shrinkage, porosity and bulk density of tri-axial porcelain tiles. Indian Journal of Research, 4(5), 58-60.

Teo, P. T., Seman, A. A., Basu, P., \& Sharif, N. M. (2016). Characterization of EAF steel slag waste: the potential green resource for ceramic tile production. 5th International Conference on Recent Advances in Materials, Minerals and Environment (RAMM) \& 2nd International Postgraduate Conference on Materials, Mineral and Polymer (MAMIP), 4-6 August 2015, Elsevier, Procedia Chemistry, 19, 842-846.

The American Ceramic Society (2005). Kiln firing chart: Pottery making illustration. Retrieved August 13, 2018, from http://www.ceramicartda ily.net/PMI/KilnFiringChart.pdf.

21 This work is licensed under a Creative Commons Attribution 4.0 International License. 